\title{
Memorial del mercader toledano Damián de Olivares, de 17 de febrero de 1626
}

\author{
Ángel SANTOS VAQuero *
}

\begin{abstract}
RESUMEN
El siglo xvII fue un siglo de crisis en toda Europa, pero más primeriza y acentuada en España. La política de los últimos Austrias produjo una grave depresión económica en la monarquia hispana que vino a unirse a la militar y a la política. Los coetáneos achacaban esta decadencia a la alta y excesiva fiscalidad que soportaba el pueblo castellano y a que el comercio se hallaba dominado por los extranjeros.

Un sector altamente afectado fue el sedero en general y el de Toledo en particular, ciudad que vio disminuir sensiblemente su población y el número de telares en producción.

Las medidas adoptadas por los gobernantes no siempre fueron las más adecuadas y acertadas; a veces hasta fueron contraproducentes y dieron ocasión a fuertes protestas de los sectores afectados, como asi sucedió con los tejedores y torcedores de seda de Toledo.
\end{abstract}

\section{ABSTRACT}

The 17th century was characterized by a crisis which spread all over Europe and intensief in Spain. The policy of the last Austrian caused a great economic depression and a military and political crisis in the Spanish monarchy. Contemporary people thought that this declive of the empire was due to the excessive tax system that Castillian people had to put up with and to the fact that foreigners had the trade under control.

The silk sector was affected and especially the city of Toledo where the population and number of looms dropped a lot.

The measures taken by the goverment were not only unsuitable but also wrong, so the people related to this trade complained especially weavers and those workers who twisted the silk in Toledo.

* UNED. 
Voces de mentes clarividentes comenzaron a criticar la política económica que se llevaba a cabo y de

Toledo, ciudad que habia sentido la crisis y despoblación con más virulencia, salieron escritos, memoriales y discursos exponiendo las causas $y$ remedios de los problemas existentes.

Uno de los toledanos que elevaron varios escritos a S.M. sería Damián de

Olivares quien, para superar la crisis, se muestra partidario del cierre de las aduanas a los géneros de seda y lana extranjeros y de permitir el libre comercio interior, con el que afirma que se genera la riqueza de las naciones.
Some discerning people began to critise the policy of the goverment and writing memorials and speeches on the reasons and solutions for the existing problems were produced in Toledo, a city which had suffered the crisis and de population very deeply. One of the men from Toledo who presented some writings to the King was Damián de Olivares. He was in favour of closing customs to silken goods and foreign wool and of letting a free domestic trade which according to him generated wealth in a country.

En el trancurso de nuestro trabajo de investigación para realizar la tesis doctoral sobre la «industria sedera toledana», tuvimos la suerte de hallar en el Archivo Municipal de Toledo un "Memorial», que juzgamos inédito, puesto que el existente en la Biblioteca Nacional está incompleto ${ }^{1}$, suponiendo sólo el $30 \%$ del documento, y no conocemos que exista otro ejemplar del mercader y arbitrista toledano Damián de Olivares ${ }^{2}$ que el del citado archivo.

La importancia de este hallazgo, reside en tres puntos esenciales: aportar más información a la historiografía existente sobre este mercader arbitrista, comprendido en el grupo mercantilista de carácter económico-productivo-industrial, de la que se ha dado en llamar "Escuela de Toledo"; conocer más profundamente su pensamiento económico y las posibles soluciones que aportaba para salir de la situación de decadencia en que se hallaba el reino hispánico y tener un cuadro más auténtico, pormenorizado y cabal de la situación socioeconómica de España en general, y de la de Toledo en particular, en el siglo XVII.

\section{CRISIS DE LA CENTURIA DECIMOSÉPTIMA}

En este siglo, por una serie de factores interrelacionados entre sí de carácter nacional e internacional, se produjo una crisis demográfica y

\footnotetext{
BibliOteCA NACIONAL, (B.N.), R-37064(2).

ARChivo Municipal de Toledo (A.M.T.), Leg. Seda $n .{ }^{\circ} 1$ (1500-1650).
} 
económica en España sin antecedentes en la historia moderna de nuestro país, si bien, este declive general ya apuntaba en el último tercio del siglo precedente, con reveses militares, hundimientos financieros y problemas socioeconómicos.

Esta crisis, que llegó a ser europea, se manifestó más prontamente en España que en el resto del continente y llegó a ser más profunda y persistente que en las naciones centroeuropeas, excepto Alemania, debido esencialmente a la altísima fiscalidad que pesaba sobre la población española y a la pésima política seguida durante los reinados de los últimos Austrias, lo que incidió de manera muy negativa en nuestras agricultura, industria y comercio. A estos males habría que añadir las mortíferas pestes que en este siglo tuvieron especial virulencia en nuestra nación y la involución económica de la América hispana, hecho que incidió en las actividades comerciales de la península al irse abasteciendo aquélla por sí misma y aumentar la introducción de mercaderías extranjeras por falta de competencia de los productos españoles ${ }^{3}$.

Esta depresión económica, a la que se unía la militar y la política, era atribuida por los coetáneos a la excesiva fiscalidad que soportaba el pueblo

3 Para una completa visión de la decadencia española del siglo xvil es preciso ver, además de las obras generales de Artola, M., La España del Antiguo Régimen. Madrid, 1966-70; CarRerA Pujal, J., Historia de la economía española, Barcelona, 1943-47; Colmeiro PENIDO, M., Historia de la Economía Politica en España, Madrid, 1965; Comellas, J. L., Historia de España moderna y contemporánea, Madrid, 1971; GENTH DA SILVA, J., Desarrollo económico, subsistencia y decadencia de España, Madrid, 1967; Gonzalez Enciso, A. y otros, Historia Económica de la España Moderna, Madrid, 1992; NADAL, J., La población española (siglos XVi a XX). Esplugues de Llobregat, $3 .{ }^{a}$ ed., revisada y ampliada, 1973; VAzQUez de PRADA, V., (director), Historia económica y social de España. Madrid, 1978; VICENS VIVES, J., (director), Historia social y económica de España y América, BarceIona, 1972 y VOL.JES BOU, P., Historia de la economia española hasta 1800, Madrid, 1972; las obras fundamentales de: Chaunu, P., Seville el I Atlantique (1504-1650), París, 1955-60; Dominguez Ortiz,

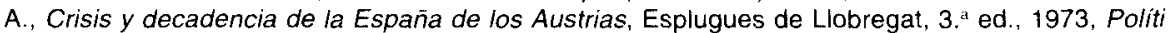
ca fiscal y cambio social en la España del siglo xvil, Madrid, 1984; Elliot. J. H., La España imperial (1469-1716), Barcelona, 4. ed., 1974; GaRCIA CARCEL, R. y otros, La España moderna, siglos XVI-XVII. Madrid, 1991; Gutierrez Alonso, A., Estudios sobre la decadencia de Castilla. La ciudad de Valladolid en el siglo XVII, Valladolid, 1989; HAMILTON, E. J., El florecimiento del capitalismo y otros ensayos de Historia económica, Madrid, 1948, El tesoro americano y la revolución de los precios en España, 1501-1650, Barcelona, 1975, Guerra y precios en España (1651-1800), Madrid, 1988; LARRAZ, J., La época del mercantilismo en Castilla (1500-1700), Madrid, 1963; LYNCH, J., España bajo los Austrias, Barcelona, 3. ${ }^{a}$ ed., 1975; PALACIO ATARD, V., Derrota, agotamiento y decadencia en la España del siglo xvil, Madrid, 3. ${ }^{a}$ ed., 1960; Pérez Moreda, V., La crisis de mortalidad en la España interior. Siglos xvi-xx, Madrid, 1980; RingROSSE. D.R., Madrid y la economia española, 1560-1850. Ciudad, Corte y pais en el Antiguo Régimen, Madrid, 1985, Imperio y Península. Ensayos sobre historia económica de España (siglos XVi-XIX), Madrid, 1987; RuIz MARTíN, F., Las finanzas de la monarquía hispánica en tiempos de Felipe IV (1621-1665), Madrid, 1990; SANCHEZ BELEN, J.A., Los Austrias menores. La monarquia española en el siglo XVII, Madrid, 1996; VINAAS MEY, C., "Cuadro económico-SOcial de la España de 1627-28. Pragmáticas sobre tasas de las mercaderias y mantenimientos, jornales y salarios" Anuario de Historia económica y social, 1, (1968), págs. 715-772. 
castellano, el cual se hallaba oprimido por los excesivos impuestos reales y municipales, sin que ello fuera suficiente para acabar con el crecido déficit público, motivo de las diferentes bancarrotas y quiebras periódicas a las que acudian los monarcas españoles y de la manipulación de la moneda con continuas revalorizaciones y deflaciones. Asimismo achacaban el declive económico a la introducción de ropas y géneros extranjeros, que se apoderaron del comercio interior y eran la causa del cese de actividad de nuestras fábricas; a la crisis demográfica; a los excesivos gastos cortesanos; a la guerra de Flandes; a la saca de metales preciosos; a la expulsión de los moriscos...

Sin embargo, no hay que olvidar otros factores que forman parte del conjunto de causas productoras de la profunda crisis a la que se vio abocada la monarquía hispana: mentalidad contraria al trabajo manual por considerarlo como una deshonra y actitud judaizante o propia de judios; falta de una auténtica burguesía industrial, financiera y comercial; nula competitividad de las manufacturas al ser el costo de producción superior al de las fábricas europeas; estancamiento en las técnicas, métodos y sistemas de producción; torpe rigidez gremial; incoherente, desorbitado y absurdo sistema impositivo; excesivo número de eclesiásticos que hacia disminuir el de los brazos productores, impedía la movilidad de la riqueza creadora de renta y contribuía al estancamiento demográfico..., la mayoria de ellos factores negativos estructurales que escapaban a la visión más localista de los pensadores que, en el siglo XVII, pretendieron honestamente, con sus escritos, sacar a España de la situación decadente que ellos palpaban, creyendo dar cada uno con la fórmula esencial y milagrosa con la que obtener los resultados que pretendian.

Pero en realidad, como señala Pierre Vilar ${ }^{4}$, la crisis española, gestada en el reinado de Felipe II, era una crisis total de nuestro sistema económico, político y social, que se manifestaba de muy diferentes maneras y en muy distintos aspectos.

Todo el sistema productivo se vio afectado, pero fue la industria sedera española, que durante el siglo XVi había visto incrementar su importancia llegando a exportar sus productos a América y a todo el continente europeo y multiplicar sus centros productores (Sevilla, Granada, Córdoba, Málaga, Murcia ${ }^{5}$, Úbeda, Baeza, Pastrana, Valencia y, sobre todo, Toledo) la que

\footnotetext{
VILAR, Pierre, Historia de España, París, 1975, pág. 64.

Esta población se significó más en la plantación de moreras y cría del gusano de seda que en la producción de ropas, aunque la fabricación de manufacturas de seda se habia iniciado en ella durante la época musulmana.
} 
se vio más duramente zarandeada por la crisis del XVII, dejándose sentir sus efectos con especial gravedad en esta última ciudad, que vio disminuir sensiblemente su población, el número de telares en producción y la pérdida de maestros sederos que emigraron sobre todo a Valencia, Granada y Madrid. Las demás ciudades también sufrieron los efectos de la crisis ${ }^{6}$. Valencia se vio especialmente afectada con la expulsión de los moriscos y con la exportación de seda cruda e hilada a Castilla, por la decadencia de Toledo, ciudad que absorbía más de las $3 / 4$ partes de la seda cruda producida en el reino valenciano ${ }^{7}$. Pero esto le serviría para ir aumentando el número de telares que trabajarian con la materia prima producida en el propio reino. Además, los sederos valencianos introdujeron nuevas técnicas procedentes del extranjero, especialmente de Génova. Así se inició en el reino valenciano la que posteriormente sería la más pujante industria sedera de España.

\section{ASENTAMIENTO DEL PROBLEMA Y PROPUESTAS PARA SU RESOLUCIÓN}

Las ciudades y las Cortes tomaron conciencia de que había que poner remedio para salvar la economia y devolver a aquéllas la actividad de sus talleres, fábricas y mercados; pero no siempre se tomaron las resoluciones adecuadas. Así, en las Cortes de 1618 se consolidó lo que sería la ruina de la fábrica de seda de España. En ellas se solicitó que no se permitiera la entrada de seda de la India, Portugal, China y Persia; sin embargo, se pidió «que S.M. fuere servido que entrase dicha seda de fuera labrada en tejidos de telas y pasamanos de buena seda fina, sin otra mezcla». Esta petición fue concedida por Felipe III por Real Cédula de 21-7-1619 expedida en Lisboa ${ }^{8}$, y se basaba en que su importación dañaba a los reinos de Granada, Murcia y Valencia, que sería motivo de ocupación para la

\footnotetext{
6 Sancho de MONCADA, señala específicamente a Toledo, Burgos, Medina y Sevilla y extiende sus efectos a "otros lugares mercantiles", mientras hace observar que han crecido y se hallan opulentas San Sebastián, Bilbao y otras partes, debido a sus tratos con los reinos vecinos, en los que no existe reciprocidad. (Restauración política de España, edición y estudio crítico de Jean Vilar, Madrid, 1974, Documento I, capitulo XII, pag.110).

Morral ! Romeu, Eulalia y Segura Más, Antonio, La seda en España. Leyenda, poder y realidad, Barcelona, 1991, pág. 75. Es de señalar que en el siglo xvı, Valencia carecia de una industria sedera importante, dedicándose casi en exclusiva a la exportación de sedas en madeja o torcida, según se desprende de las peticiones realizadas en las Cortes de 1537 y 1547 , así como de un edicto que en 1561 publicó el Virrey. Ver Carrera Pujal, J., Historia de la Economía española, vol. II, Barcelona, págs. 505, 508 y 511.

8 Archivo Histórico Nacional (A.H.N.), Cons. Lib. 1531, núm. 18, 2 h. Fol. (págs. 119121).
} 
gente pobre y se evitaría la salida de dinero del país. Se permitía, como indicaba la petición de las Cortes, la entrada de seda tejida, telas y pasamanos, siempre que la bondad y calidad de los mismos fueran reconocidos por los maestros del arte nombrados para examinarlos.

Sin embargo, no todos los sectores estuvieron conformes con esta medida. Así, el gremio de torcedores de Toledo se manifestó en contra de la susodicha Real Cédula porque les perjudicaba al faltar seda y encarecerse la existente en demasía. Pero no sólo fueron los maestros torcedores los que enarbolaron la bandera contra la Real Cédula de 21-7-1619, también los maestros y oficiales del Arte mayor de la Seda se manifestaron en contra, advirtiendo que con esta medida sólo se beneficiaba a los cosecheros de Valencia y Murcia, mientras perjudicaba a las ciudades con industria sedera pero sin materia prima. En 1621 se rectificó algo, pues aunque se vuelve a solicitar la prohibición de las importaciones de seda en crudo o en madeja, se hace extensiva esta vez la veda a la seda labrada o tejida, a fin de contener el declive, la ruina y despoblación de las ciudades que vivían de esta industria, poniéndose como ejemplo a Granada, de la que se dice que de 5.000 telares que había tenido la ciudad, se había pasado a 400 . Sevilla no marchaba mucho mejor pues, según Campomanes, los tejedores de seda y lana al advenimiento de Felipe II tenian en esta ciudad 16.000 telares, y a la muerte de su hijo sólo quedaban en producción $400^{9}$.

Ya en la época, además de los gremios perjudicados, hay personajes que critican esta política económica que era la ruina de nuestra producción nacional, como Sancho de Moncada, quien en 1618 opinaba que el daño no provenía de entrar seda, sino de traer tejidos de fuera porque se gastaban los extranjeros y no se tejían en España. Este pensador propugnaba la veda a las mercancías labradas en el extranjero, pues eran causa del aumento del ocio y de hacer desaparecer las artes en España, empobreciéndola "porque todas las mercaderias labradas tienen gran parte de obraje y fábrica (...) y todo este aprovechamiento chupan y sacan extranjeros de España y lo pierde el español, que es con lo que se habia de sustentar la mayor parte del reino" ${ }^{10}$, poniendo como ejemplo a Francia, Flandes, Génova y Venecia, repúblicas que, según su criterio, antes eran pobres y se habían enriquecido labrando mercadurías, o como D. Fernando de Rojas, quien en 1623, en su discurso sobre la moneda,

9 Rouriguez Campomanes, Pedro, Discurso sobre la educación popular de los artesanos y su fomento, 1775, Tomo II, pág. 472.

10 Moncada, Sancho de, op. cit, Discurso I, cap. XII, pág. 110. 
expuso que lo que debia prohibirse era la entrada de labores y no la materia prima ${ }^{11}$.

Ya en 1603 el gremio sedero de Toledo había elevado sus quejas contra la entrada de sedas y tejidos extranjeros, esencialmente de Italia, pues dañaban a su fábrica y a las gentes que de ellas se sustentaban, asi como a los compradores, al haberse comprobado la falsedad y la menor cuenta de tales tejidos. En la misma línea escribían el doctor Bautista Suárez y el licenciado Juan de Lara. Este último, en su escrito de 12 de febrero de dicho año, exponia que la entrada de sedas y tejidos de Italia iba contra lo dispuesto por las leyes reales y dañaba a Toledo, donde habia más de 14.000 personas que se sustentaban con la labor diaria de la seda, las cuales padecian escasez por culpa de esta invasión. En nombre de los maestros del Arte de la Seda de esta ciudad pide que se apliquen y guarden las leyes del reino y sus ordenanzas sobre el uso y ejercicio del tejer y se impida la entrada de tejidos de seda de fuera de España ${ }^{12}$.

Es en esta época, sobre todo a partir de 1618, con la caída del valido duque de Lerma y la subida a la privanza del conde-duque de Olivares, cuando surgen los "arbitristas", quienes, en sus abundantes escritos, en general, proponen sistemas o planes financieros disparatados o empíricos que piensan infalibles, pero que no tienen fundamento sólido para resolver las dificultades públicas, económicas o de otra clase, coyunturales o estructurales, porque parten todos ellos de una perspectiva particularista y local, con visión sólo de aspectos parciales y diversos de una realidad más global, lo que les impide hallar las raices profundas del colapso español. Los remedios propuestos por estos pensadores, en su mayoría eran poco científicos; planteamientos y medidas, la mayoría extravagantes, irrealizables, utópicos, faltos de sentido y contrarios a la libertad individual. Sólo en algunos casos, esencialmente de aquéllos que rechazaban la denominación de «arbitristas», son dignos de tenerse en cuenta y posiblemente hubiesen resultado muy positivos para nuestra economía de haberse llevado a efecto.

Toledo, la ciudad que más habia sentido la crisis y despoblación en la Meseta Sur, debido a su condición de auténtico centro industrial y mercantil, dio a luz hombres (regidores, jurados, mercaderes, catedráticos, profesores, jurisconsultos, poetas, doctores...) que con sus escritos, memoriales y

11 Garzón PAREJA, M., La industria sedera en España. El arte de la seda en Granada, Granada, 1972, págs. 165-66.

12 A.M.T., Escritos todos ellos guardados en el Leg. Seda n. ${ }^{\circ} 21$. 
discursos intentaron defender el bien común, exponiendo sus planes e ideas con los que pretendian dar solución a los problemas existentes: Sancho de Moncada, Alonso de Narbona, Jerónimo de Ceballos, Elisio de Medinilla, Garcia Herrera de Contreras, Juan Belluga de Moncada, Fernando Álvarez de Toledo, Pablo de Moncada, Juan Vázquez, Garcés de Molina, Pedro Hurtado de Alcocer, Damián de Olivares ${ }^{13}$... Muchos de ellos propusieron medidas

13 Para conocer la obra de estos pensadores O «arbitristas», podemos consultar a VILAR, Jean "Docteurs et marchands: l'école de Tolède (1615-1630)", V Congreso Internacional de Historia Económica, Leningrado, 1970, Literatura y economia. La figura satírica del arbitrista en el Siglo de Oro, Madrid, 1973, “Un pessimisme calculé: l'introspection economique à Tolède (1616-1628)" en Tolède et lexpansion urbaine en Espagne (1450-1650), Rencontres de la Casa de Velázquez. Actes du colloque organisé par la Junta de Comunidades de Castilla-La Mancha et la Casa de Velázquez, Tolède-Madrid, 21-23 mars 1988, Madrid, 1991, págs. 99-116; MARTz, Linda, "La familia y la hacienda del doctor Sancho de Moncada", Anales Toledanos, XXIX, 1987, págs. 51-90; ARANDA PÉREZ, FCO. José, "La preocupación arbitrista en el seno del Ayuntamiento de Toledo por la declinación de la ciudad en un período crítico: 1618-1621", Toletum, n. ${ }^{\circ} 29,1993$, págs. 201-227; COLMEIRO, Manuel, Biblioteca de los economistas españoles de los siglos xVI, xv"l y xvili, Madrid, 1979, Los políticos y arbitristas españoles en los siglos xvi y xvil y su influencia en la gobernación del Estado, Discurso leido ante la R.A. de la Historia, Madrid, 1857; Sureda CARRion, J.L., La hacienda castellana y los economistas del siglo xvil, Madrid, 1949; RodrigueZ DE Gracia, Hilario, “Alonso de Castro Xibaje: un arbitrista del siglo xvil» en Tolède ef l'expansion urbaine en Espagne (1450-1650) (op. cit.); GutiérRez NIETO, V., "El pensamiento económico, politico y social de los arbitristas" en Historia de España de Menéndez Pidal. El siglo del Quijote (1580-1680). Religión. Filosofia. Ciencia, tomo XXVI, vol. I, Madrid, 1987, págs. 234-346; ELLIOT, J. H., «Introspección colectiva y decadencia en España a principios del siglo XVII", en Poder y Sociedad en la España de los Austrias, Barcelona, 1982; PALACIO ATARD, Vicente, Derrota, agotamiento, decadencia en la Espoaña del siglo xvil, $2{ }^{2}$ edic., Madrid, 1956; PERdices de BLAS, Luis, La economia política de la decadencia de Castilla en el siglo XvI: investigaciones de los arbitristas sobre la naturaleza y causas de la riqueza de las naciones, Madrid, 1996, El florecimiento de la economia aplicada en España: arbitristas y proyectistas (siglos XVl, xVII y XVIII), Madrid, 1992, La restauración de la riqueza en España por la industria. Reflexiones sobre el industrialismo de los arbitristas del siglo xVII. Madrid, 1993; CORREA CALDERON, Evaristo, Registro de arbitristas, economistas y reformadores españoles. 1500-1936, Madrid, 1981, “Invenciones, fantasías y paradojas de los arbitristas", Arbor, n. ${ }^{\circ} 395,1978$, págs. 7-22; DE MONCADA, Sancho, Restauración política de España (Reedición facsímil a cargo de Jean Vilar, Madrid. 1974); Fernandez de Navarfete, Pedro, Consenación de monarquias y discursos politicos, (edición y estudio preliminar de Michael D. Goidon, Madrid, 1982); CAXA DE LERUELA, Miguel, Restauración de la abundaricia en España, (edición a cargo de Jean Paul Le Flem, Madrid, 1975); AlbiñanA, Salvador, "Notas sobre decadencia y arbitrismo", Estudis. Revista de Historia Moderna, n ${ }^{\circ} 20,1994$. págs. 9-28; BALDuOUe Marcos, Luis Miguel, «El pensamiento arbitrista en los primeros años del gobierno de Olivares: la obra de Guillén Barbón y Castañeda", Cuadernos de Historia Moderna, ${ }^{\circ}{ }^{\circ}$ 12, 1991, págs. 223-240; ÁlVAREZ VÁzQUEZ, José Antonio, "Arbitristas españoles en el siglo XVII", Cuadernos Hispanoamericanos, $n .^{\circ} 334,1978$, págs. 55-75; Dominguez OrTIz, Antonio, "Nuevos ejemplos de un género muy español: El arbitrismo económico del siglo XVII", Hacienda Pública Española, n. ${ }^{\circ} 100,1986$, págs. 275-285, Politica y Hacienda de Felipe IV, Madrid, 1960; DE LA IGLESIA, Jesús, “Economistas políticos, memorialistas y arbitristas en la España del siglo XVli», Anuario Jurídico y Económico Escurialense, n. ${ }^{\circ} 29,1996$, págs. 927-947; BARAT, Mercedes, “Un texto arbitrista del siglo XVII: El memorial de Ángel Manrique", Cuadernos de Historia Moderna y Contemporanea, n. ${ }^{\circ}$ 2, 1981, págs. 105-125; Gonzalez de Cellorigo, M., Memorial de la politica necesaria y útil. Restauración a la República de España y estados de ella y del desempeño universal de estos reinos (1600). (edición y estudio preliminar de J.L. Pérez de Ayala, 1992). 
concretas, algunas impracticables o perjudiciales, como después pudo comprobarse cuando se cerraron las fronteras a ciertos productos extranjeros y hubo que rectificar con prontitud; otras nada prácticas y las menos, dignas de haberse tenido en cuenta y de ponerse en ejecución.

Las mentes más clarividentes ya se dieron cuenta de que la solución para desarrollar la industria no residía en la supresión de la competencia exterior ni en medidas restrictivas del comercio, sino en la eliminación de barreras aduaneras interiores, pues con ello a quien se perjudicaba era a los productos nacionales que tributaban más que los extranjeros porque el fisco estaba pensado para recaudar dinero y no para favorecer la industria del país. Como ejemplo significativo tenemos las palabras de D. Diego Sarmiento de Acuña, conde de Gondomar:

\footnotetext{
«Parece convenientísimo quitar en España todas las aduanas de tierra firme, y lo que montan los derechos crecerlo en los puertos de mar, donde lo contribuirán los forasteros y no los naturales, que son los que trafican tierra adentro; y con esto podrían comerciar y tratar sin los impedimentos que hoy tienen; (...) $y$ todas estas vejaciones hechas a los vasallos de Su Majestad son en beneficio de Inglaterra, porque les es más cómodo a todos los de Galicia, Asturias y Vizcaya, Aragón, Valencia, Cataluña, Andalucia y Portugal traer el paño de Londres que de Segovia y este es punto que se debe mirar mucho" ${ }^{14}$.
}

No sólo era la industria sedera la que padecía los efectos de la crisis, también la muy consolidada y acreditadísima industria pañera segoviana se vio sumida en este proceso de hundimiento ${ }^{15}$. En ésta incidieron todos los males de la economía española, a los que se unieron la escasez de materia prima, al preferir los ganaderos vender sus lanas en el exterior por serles más rentable, y la enemiga francesa, con la política agresiva de Colbert contra las telas extranjeras. Otras ciudades como Cuenca, Toledo, Béjar, Palencia..., vieron disminuir o casi desaparecer sus telares de géneros de lana, incrementando el número de parados y llevando la desolación a las gentes que, llegando al límite de su aguante, explotaron en motines y violencia como en Toledo y Andalucía entre 1647 y 1652.

14 Cita tomada de Regla Campistol, J., Introducción a la Historia de España, Barcelona, 1972 (novena edición corregida), pág. 389.

15 Para un amplio conocimiento de este tema ver, además de los autores y obras refiejados en la nota $n .{ }^{\circ} 3$, Fontana LazARo, José $M{ }^{a}$, La lucha por la industrialización de España, Madrid, 1955; Rodaiguez VILLA, Antonio, "Industria española. Su desarrollo en los siglos XVI al XVIIl", Revista de Archivos, Bibliotecas y Museos, II, 1872, págs. 291-324; Ruiz MARTiN, F., “Un testimonio literario sobre las manufacturas de paños de Segovia por 1625". Homenaje al Profesor Alarcos, tomo II, 1966; Garcia Sanz, A., Desarrollo y crisis del Antiguo Régimen en Castilla la Vieja, Madrid, 1977; García Fernández, Jesús, Desarrollo y atonia en Castilia, Barcelona, 1981. 


\section{DECADENCIA DE TOLEDO}

La situación de Toledo en el siglo XVII era calamitosa ${ }^{16}$. Ya en 1618, el doctor García Herrera escribe que "los oficios paran, los tratos se disminuyen, las casas no se alquilan, los juros no se pagan ni se cobran, los frutos de la tierra no se venden" ${ }^{17}$. En 1620, Jerónimo de Ceballos pinta la situación de Toledo como una ciudad con usus calles desiertas, el trato perdido, la labranza desamparada, las casas cerradas y sin moradores, las rentas reales en la mayor quiebra que jamás se ha visto y los que las arriendan aniquilados" ${ }^{18}$. Este mismo licenciado y regidor del Ayuntamiento de Toledo expone en su discurso "Para la determinación de la concesión de millones desde el año de 1619" que "en Toledo no se han arrendado este año las rentas reales por no aver trato y estar todos perdidos (de lo cual soy buen testigo, porque en nueve años que las administro por mandado del Consejo de Hacienda no se ha visto semejante cosa)..." ${ }^{19}$.

Muy importantes son, asimismo, los escritos de Damián de Olivares por las noticias que nos aportan sobre la situación de Toledo durante los reinados de Felipe III y Felipe IV, y los de Juan Belluga de Moncada.

La industria textil toledana había sido la más importante de toda la submeseta sur castellana durante la Edad Moderna y, hasta mediados del siglo XVII, la de mayor valor y alcance, la más numerosa y de mayor prestigio, reputación, crédito y prosperidad de nuestra nación ${ }^{20}$. Sólo con la sedera se sustentaban 20.000 personas ${ }^{21}$. Parece que hubo registrados en

16 Sobre la decadencia de Toledo en el siglo XVII es necesario ver las obras de: MARTINEZ GIL, Fernando, Toledo y la crisis de Castilla, 1677-1686, Toledo, 1987; Molina Merchan, Enrique C., Toledo en la crisis del Antiguo Régimen, Toledo, 1984; MONTEMAyOR, Julián, "Toledo en 1639 ", en Melanges de la Casa de Velázquez, Paris, 1982; Rodriguez dE Gracia, Hilario, Asistencia social en Toledo, siglos XVi-xvm, Toledo, 1980, Pobreza y beneficencia en la provincia de Toledo (15001800). Toledo, 1983; SAnchez SANCHEZ, Juan, Toledo y la crisis del siglo Xvir. El caso de la parroquia de Santiago del Arrabal, Toledo, 1980.

17 Tomado de COLMEIRO PENIDO, Manuel. Historia de la economia política en España, 2 vols., Madrid, 1965, vol. II, pág. 777

18 lbidem.

19 B.N., V.E., 200-67, (impreso de 5 folios, sin fecha). Del Discurso del Licenciado Gerónimo de Cevallos, Regidor de Toledo y su Comisario para la determinación de la concesión de millones deste año de 619, adonde se disputa si es justa la demanda de su Magestad, y si se le puede negar la Contribución estando el reino en estrema necesidad y el Rey nuestro señor en la misma. Dirigido a D. Fernando de Acevedo, Presidente del Consejo de Castilla. A instancia de D. Garcia Suárez de Canajal, Corregidor de Toledo, caballero del hábito de Calatrava y señor de las villas de Peñalver y Alhóndiga.

20 Ver representación impresa elevada por el Ayuntamiento de Toledo al Rey el 28-7-1747, A.M.T., Leg. Seda n. ${ }^{\circ} 4(1700)$.

21 Archivo General de Simancas (A.G.S.). Patronato, 15-11, Memorial impreso que presentó Juan Belluga de Moncada sobre la decadencia de Toledo, sus causas y remedios (1621). 
la ciudad y su jurisdicción más de 30.000 telares ${ }^{22}$. Sin embargo, a partir del ecuador de la centuria decimoséptima, comienza el declive de esta industria, aunque la ciudad ya había notado su decadencia, como se ha indicado arriba, desde finales del siglo anterior, y desde aquel momento fue superada por Sevilla, Granada y Valencia, entre otras. El principal motivo de ello fue la falta de renovación técnica y de métodos productivos, aunque los hombres de la época lo achacaban a otras causas: conculcación de las Ordenanzas, entrada de tejidos extranjeros, manipulación de la moneda, alta presión fiscal, traslado de la Corte a Madrid...

No sólo la industria textil fue la afectada por la crisis, también se hundieron las de loza, vidrio, curtidos, armas blancas y otras de menor importancia. Esto se demuestra con la huída de la ciudad de los trabajadores de estos ramos, pues como dice Juan Belluga de Moncada.

"de calles enteras que havia de freneros y armeros, vidrieros y otros oficios semejantes, no ha quedado un solo oficial, pues no se hallara en la dicha ciudad un frenero que haga ni aderece un freno de caballo ni mula, ni un armero ni arcabucero, y sola una miserable tienda de vidrios ha quedado en la dicha ciudad (...) Y un trato gruesso de boneteria que avia en ella, de que se provehia toda Africa en que se entretenia y con que se sustentaba gran numero de gente, esta casi perdido y arruynado" ${ }^{23}$.

El mercader toledano Damián de Olivares, a quien podemos considerar perteneciente a lo que se ha venido en llamar "Escuela de Toledo" (conjunto de personalidades que a principios del siglo XVII fueron altamente sensibles a la situación de degradación de España, y en especial de Toledo, como capital exponente de la misma junto a Segovia y Sevilla, y que elevaron a distintas personalidades e instituciones una serie de memoriales y escritos expresando cuáles eran, según su criterio, las causas de los males que aquejaban a la monarquía hispánica y sus remedios), aunque no era de la élite local por preparación intelectual y por motivos sociales (no formaba parte del claustro de doctores de la Universidad como Sancho de Moncada, ni del cabildo de jurados como Alonso de Narbona, ni del de curas como Juan Vázquez), participaba de su misma sensibilidad económica y coincidía con los demás pensadores-escritores en la consideración de la crisis, sus causas y principal remedio: solamente una firme prohibición, un exhaustivo control fronterizo, salvaría la situación creada.

\footnotetext{
22 Según Memorial de la ciudad de Toledo a S.M. de fecha 26-8-1739, A.M.T., Leg. Seda n. $4(1700)$.

23 A.G.S., Patronato, 15-11, Memorial impreso de Juan Belluga de Moncada sobre la decadencia de Toledo, sus causas y remedios (1621).
} 
Más conocedor del ambiente mercantil que los doctores universitarios, procura dar cifras de las pérdidas del sector textil y es únicamente en éste sobre el que pide que se actúe dado que es el que más atañía a Toledo. A la vez, se obsesiona por el hecho americano, por su mercado seguro en otro tiempo para España y sobre todo para la exportación textil de Toledo y que ahora se habia perdido en favor de los extranjeros, quienes lo dominaban y enviaban a las indias los géneros que más les convenian ${ }^{24}$.

Este planteamiento era el denominador común de los pensadores económicos pertenecientes a la "Escuela de Toledo", ya que todos los escritos de sus componentes, representados en Sancho de Moncada ${ }^{25}$, coincidían en plantear como el primero y principal motivo de la decadencia de España que los extranjeros se habian apoderado del comercio, con lo que se llevaban las materias y el dinero, porque por la política gubernamental errónea del libre comercio se les permitía la libre entrada de productos textiles de fuera y ello traía como consecuencia la destrucción del tejido productivo nacional y el hundimiento demográfico ${ }^{26}$.

El ya citado mercader Damián de Olivares, nos presenta el panorama hacia 1620, refiriéndose a los tratos y negocios de la lana y la seda, diciendo:

"Son tan grandes que solo Toledo ha sido siempre bastante a proveer de mercaderias todos estos Reynos de España, y fuera de ella, y para las Yndias en las armadas que se cargavan, la mayor parte que se cargava era labrado y fabricado en esta Ciudad la qual estava tan poderosa que no solo ella se sustentava sino que era bastante a mantener a mas de cinquenta pueblos en su contorno, que trayan a vender a esta Ciudad, y era en tanta cantidad que deziamos que la mayor feria de España era el meson de los paños de Toledo: todo lo qual se ha acabado, y esta en tanta disminucion que el negocio de la seda, que era el mas gruesso que avia en España, y que no solo se sustentava la mayor parte de Toledo, mercaderes y oficiales, sino que venian muchos de otras partes a trabajar y a tratar en ella, y oy se van todos los que vinieron y los que se estavan, y los oficiales del dicho trato con estrema necessidad dexan sus casas, mugeres, y hijos, en contingencia de sus honras... y los mercaderes por aver cesado el dicho trato, se van acabando y consumiendo, y cada dia se va conociendo mas con las nuevas quiebras que de ellos se ve, y esto es tan aprisa y de tal manera que

24 Ver Jean V:LAR, “Un pessimisme "calculé": l'introspection économique à Tolède (16161628)", en Tolède et l'expansion urbaine en Espagne (1450-1650), Rencontres de la Casa de Velázquez, Actes du colloque organisé par la Junta de Comunidades de Castilla-La Mancha et la Casa de Velázquez, Tolède-Madrid, 21-23 mars 1988, Madrid, 1991, págs. 117-136.

25 Restauración..., op. cit.

26 Según Damián de Olivares, a 127.823 personas ascendía el número de afectados por la crisis del sector textil en las ciudades de Toledo y Segovia. Ver VILAR, Jean, "Un pessimisme "calculé"... op. cit., pág. 133. 
si Dios no lo remedia de oy en diez años ha de quedar esta Ciudad acabada de arruynar, sin le quedar ningunas fuerças, ni esperança de poder bolver en si.... 27 .

El mismo Damián de Olivares, refiriéndose a la industria sedera de Toledo en un memorial suyo publicado el 27 de julio de 1620, con el título: "Memorial de Damian de Olivares, natural de la ciudad de Toledo, el primero que dio arbitrio para que en estos reinos, ni en las Indias no entren mercaderias estrangeras, labradas de lana, ni seda de ninguna suerte que oy entran, ni de obra alguna que inventaren, el cual es para representar a su Magestad, y á la insigne y piadosisima junta, los daños que recibe el Reino de su entrada, reducida a quenta por menudo, y para resolver a la nueva duda que en este casso se a tenido. Dirigido al llustrissimo Señor Don Fernando de Acevedo, Presidente de Castilla y Arzobispo de Burgos" ${ }^{28}$, escribe que en la ciudad había entre 5 y 6.000 telares de seda para los que, calculando a 110 libras de seda cada uno para mantenerse en activo durante todo el año, se necesitarían 605.000 libras anuales en total ${ }^{29}$. Debe referirse sólo a los de ancho, pues luego dice que "sin que tratemos de la seda que se gastava en medias, listones, pasamanos y reforzadas y otras menudencias que no cuento, por resguardo de la moderacion de esta cuenta" que se hacian en los llamados telares de angosto o telarillos, que solían ser manejados por mujeres, quienes de esta manera obtenían un sobresueldo o jornal adicional; por lo tanto no es extraño se hablase de haber habido en Toledo 30.000 telares, aumentando esta cifra algunos otros autores a 40.000 , y refiriéndose no sólo a la capital sino a pueblos de su contorno, que también se dedicaban a este menester (Fuensalida, Ajofrín, Yepes, Villasequilla, Villaseca, Novés, Magán...) ${ }^{30}$.

Sin embargo, el número de telares indicado anteriormente había quedado reducido, según el mismo mercader, a 500, para los que calculaba, añadiendo la seda necesaria «para medias y demás menudencias», se

\footnotetext{
27 B.N., R-V.E. 210-59, A la Imperial ciudad de Toledo, Memorial presentado por Damián de Olivares, 4 fols.

28 Tomado de Martin Gamero, Antonio, Los cigarrales de Toledo, Toledo, 1857. Reproducción en facsímil, Valencia, 1992, págs. 153-156.

29 Dato que concuerda con el proporcionado por los veedores del Arte de la Seda de Toledo en un informe elevado y visto en el Ayuntamiento de la ciudad el 14-5-1687, donde se dice que en 1619 había en Toledo 5.000 telares de todos géneros de seda, A.M.T., Leg. Seda n. 3 (16911699).

30 A.M.T., Carp. Seda (1500-1650), n. ${ }^{\circ}$; Carp. Seda, lana y telares (1700-1800), n. ${ }^{\circ} 20$ y memorial de la ciudad de Toledo a S.M., de fecha 26-8-1739, Leg. Seda $n .^{\circ} 4$ (1700). De ser cierta esta cifra, debe tener en cuenta tanto los telares de ancho como los de angosto o telarillos, siendo estos últimos numerosísimos tanto en Toledo como en los pueblos cercanos.
} 
precisaban de 160.000 a 170.000 libras, lo que significaba una reducción de 435.000 libras de seda menos que en los tiempos de prosperidad de Toledo y su partido, con lo que quedaban unas 38.480 personas sin oficio y se dejaban de ganar 44.065 .000 reales anuales sumados el valor de la seda a 50 rs. la libra $(21.750 .000$ rs.) y el valor de su elaboración (22.315.000 rs.).

La causa de semejante desastre la achacaban los hombres de la época a la permisión para traer de fuera géneros similares que, aunque de peor calidad (según decian ellos), eran más apreciados por sus colores más agradables y vistosos, a la vez de por su mayor baratura. Esto se veía agravado, en el caso de las labores de lana, por el hecho de estar fabricados con la vendida en bruto por los ganaderos de este reino, con lo que se originaban múltiples daños: se paralizaban los talleres, aumentaba el paro, se encarecía la materia prima, se debilitaba el comercio de nuestra ciudad y la ganancia quedaba fuera de nuestras fronteras ${ }^{31}$.

\section{DEL MEMORIAL INÉDITO}

En el memorial que nos ocupa, y que es el motivo de este trabajo, publicado por Damián de Olivares con fecha 17 de febrero de 1626, continúa mostrándose partidario de que se cerrara la entrada en España de mercaderías de seda y lana labradas en el extranjero y que se gastasen las producidas en el reino, a fin de que quedase en él la riqueza generada.

En este memorial, por el que sale en defensa de Diego de Balsamo y otros mercaderes de Toledo a quienes los alguaciles Francisco de Aguilera y Damián Bravo habian denunciado por proceder contra lo que ellos denominaban «estanco" de la seda, para tornarla a vender sin mudar de especie y comprar tejidos para hacer otro tanto, nos confirma que por esas fechas entraban en Toledo 150.000 libras de seda, poco más o menos, por un valor de millón y medio de reales de vellón ${ }^{32}$. Dicha seda era vendida

31 Escrito de petición, elevado por los veedores del Arte de la Seda de Toledo s/f. (1668), A.M.T., Leg. Seda n. ${ }^{\circ}$ (1500-1650).

32 En este memorial, Olivares nos manifiesta que en Valencia se cogían más de 400.000 libras de seda, en Murcia otras 200.000 y entre Granada y Extremadura y lo demás de la tierra, otras 100.000 . Estas cantidades concuerdan mal con lo que él mismo indica en su otro memorial de 1620 , pues si Toledo, cuando tenia 5.500 telares acaparaba 605.000 libras como minimo, ello supone la casi totalidad de la cosecha de España, el $86,5 \%$ exactamente y, si por lo que sabemos, no se importaba seda de Granada ni de Extremadura, tenía que traer el $100 \%$ de la producida en la zona levantina, cosa totalmente imposible ya que en Valencia se necesitaba abundante seda para su propia producción de tejidos y además se sabe que se exportaba a Granada 
en la ciudad por más de 30 casas que se dedicaban a este menester, unas por comisión y otras por compra directa. Además de este modo, también entraba seda en la ciudad comprada directamente por quienes iban a labrarla o traída por forasteros cada día para venderla en el mesón de la seda.

En 1651 la cantidad de seda consumida en la ciudad había bajado a 104.375 libras según certificación de Blas Fernández de Messa, Contador de las alcabalas y cientos de Toledo y Mayor de su Ayuntamiento. Esta seda no sólo correspondía a la ciudad, sino también a las villas y lugares de su partido donde se trabajaba esta materia. De ellas 95.473 correspondían a seda fina de Valencia y Murcia, 8.306 de seda ocal ${ }^{33}$ (adocal) y de la tierra (la adocal de Valencia) y 596 de filadis ${ }^{34}$ de Valencia y Murcia ${ }^{35}$.

La guerra sostenida entre el gremio de sederos y los mercaderes de Toledo, era muy particular. Los primeros protestaron y denunciaron lo que ellos denominaban el "estanco" de la seda por los "comisionados" de Valencia y Murcia, quejándose de que acaparaban la seda, vendiéndola a quien querían y al precio que les parecia, con lo que perjudicaban a los tejedores que antes la compraban en el "Mesón del lino" directamente y en mercado abierto a los dueños de ella. Aseguraban que este sistema actual traía como consecuencia un alza del precio de la seda y el desconocimiento por parte de los laborantes de la calidad y cantidad de la existente; que no había competencia entre los comisionados, pues entre ellos hacían "liga y monipodio"; que daba ocasión a un aumento del fraude a la Hacienda real, y lo demostraban diciendo que con el sistema anterior la seda que se movía en Toledo producia 14 ó 15 millones de maravedís de la alcabala y desde que los comisionados se habían introducido su baja había sido considerable, llegando algunos años a sólo 4 millones y nunca había sobrepasado los 6 , siendo la causa los fraudes que los mismos hacian a la entrada de la seda en la ciudad, ocultándola hábilmente y luego guardándola en escondrijos inverosimiles: casas particulares, sótanos, aljibes, iglesias, sepulcros, cuevas...

Por el contrario, los mercaderes aducian que siempre había habido comisionados, que éstos eran necesarios para el comercio, pues era imposible que los dueños de la seda de Valencia y Murcia viniesen por

\footnotetext{
y a otras partes del extranjero. Así que, o la producción era mayor o en Toledo no podia entrar tal cantidad de seda.

${ }_{33}$ La de inferior calidad, pero fuerte, que se saca del capulio ocal.

34 Filadís o filadiz, pelo de seda extraído del capullo roto por la mariposa o del mal acabado por haber muerto el capullo antes de perfeccionarle. No se puede hilar con los demás, por lo que se beneficia limpiándole y cociéndole con jabón y después se lava con agua clara y se hila. Los murcianos llaman asi a la seda formada por los gusanos sin hacer el capullo.

35 A.M.T., Certificado de 14-7-1652. Leg. Seda n. ${ }^{\circ} 1$ (1500-1650).
} 
si mismos a venderla a Toledo, al igual y como lo hacian los comerciantes toledanos en otras ciudades y reinos con sus géneros, y que además, entre otras cosas, así se aseguraba la existencia de materia prima en la ciudad. Que no era que se vendiese a quien se quisiese, sino a aquéllos que eran seguros pagadores o a los que merecían crédito suficiente. Es decir, Damián de Olivares se mostraba partidario de un mercado libre interior, donde a semejanza de las leyes de evolución de la naturaleza, sólo los más fuertes y preparados sobrevivían, dejando que los débiles, los pobres, desaparecieran por inanición.

Por todo lo cual, los tejedores y gremio de sederos demandaban que se prohibiese la existencia de comisionados de Valencia y Murcia, según las leyes del reino (pragmática de 2-6-1600) ${ }^{36} \mathrm{y}$ ordenanzas de Toledo, por las que nadie podía comprar seda y volverla a vender en la ciudad del Tajo sin antes haberla beneficiado (teñirla o darla dispuesta para tejer) y que todo forastero tenía que ponerla en el mesón señalado a tal efecto para que allí la comprase quien la necesitara, sin ocultación ni reserva.

Ya Felipe III había dado una provisión con fecha 14 de mayo de 1599 por la que mandaba expresamente a las autoridades de Sevilla, Toledo, Granada, Córdoba, Murcia, Jaén, Úbeda y Baeza, asi como al resto de las demás villas y lugares de sus reinos, tanto de realengo como de señorío, que debido a la carestía que se había producido en la seda de algunos años a esa parte y creyendo que se debía a dos causas: la existencia de "regatones" que o bien la tenian comprada antes de que se acabase de criar o la compraban después en crudo o en madeja para revenderla, y al fraude de mezclar la seda fina con la llamada ocal, que era de mucho menos valor y provecho pues reducía la duración del tejido que con ella se labrase, prohibia que ninguna persona de sus reinos pudiera comprar capullo de seda ni seda cruda ni en madeja para volverla a vender en la misma especie así como el mezclar la fina con la llamada ocal o redonda en telas ni en otra cosa alguna, ni se hilase ni tejiese toda junta ni mezclada, sino cada una por sí. Esta medida la tomó el monarca después de haber consultado a los Ayuntamientos, con los que se tuvo una reunión con personas de experiencia y conocimiento en lo tocante al arte de la seda ${ }^{37}$.

Sin embargo, al igual que se dio una pragmática el año 1552 por la que nadie podía comprar lana para volverla a revender y ya en la Cortes

\footnotetext{
36 Pragmática dada en San Lorenzo de El Escorial para que "el que comprase seda en capulio, maço o en madeja, no la pueda tornar a revender, sino fuera teñida, o texida, ni se eche en ella miel, xabon, ni otras cosas, ni mezclar con la fina la ocal o redonda". Madrid, Luis Sánchez. 16, A.H.N., 4 h. fol.; Osuna, leg. $2269, n .^{\circ} 3$.

37 A.M.T., Archivo Secreto, Cajón n. ${ }^{\circ} 5$, leg. 4, n. $^{\circ} 28$.
} 
de Valladolid de 1555 se hizo petición (la $\mathrm{n} .^{\circ} 82$ ) de que se suspendiese dicha pragmática por ser más los daños que causaba que los beneficios que se habian pretendido, pues al no haber revendedores de la lana, los pobres laborantes no podían comprarla directamente al faltarles caudales suficientes y nadie se la fiaba, por lo que se mandó suspender la citada orden; así por la Pragmática real dada en Madrid el 3 de junio de 1600 se mandaba que nadie pudiese comprar sea para volverla a vender sin cambiarla de especie, y viéndose que producia los mismos malos frutos que aquella de la lana, se suspendió por carta acordada de 28 de diciembre de 1608 para que hubiese posibilidad de comprarla y venderla libremente ${ }^{38}$, pues, aducian los comerciantes y hombres de negocios, que el libre comercio trae la abundancia de productos "por codicia de ganar» y esta misma abundancia producía una baja del precio.

Este argumento le sirve a Damián de Olivares para solicitar amparo, aliento, protección y ayuda para los hombres ricos que fomentaban el comercio e industria contra los que los calumniaban con vejaciones y denuncias, prendiéndolos, molestándolos y quitándoles sus créditos, porque esas molestias eran causa de que abandonaran sus actividades y de que aquellos otros, que tenían el proyecto de dedicarse a esos negocios, desistiesen de ejercerlos.

Estima necesarios e imprescindibles los caudales para el aumento de las fábricas y labores del reino y por ello razona que es justo y necesario alentar y ayudar a los que los emplean en ese menester, procurando evitar que se les moleste, persiga o acucie con normativas más perjudiciales que beneficiosas; que se les deje actuar libremente, sin trabas o prohibiciones, pues con su codicia de ganar, su riqueza producirá riqueza al reino, aumentará el trabajo y el bienestar general. Además, concluye en su razonamiento, las fábricas dan de comer a ricos y pobres. Para que trabajen y coman los pobres, que constituyen la mayoria de la población, juzga necesario que haya hombres acaudalados que den trabajo, fiando las materias para la labor a los productores y asegurándoles la compra de lo fabricado.

Ya hemos dicho que Toledo era una ciudad que carecía de seda en rama y sin embargo poseía una industria sedera de las más importantes de España. La seda que esta fábrica necesitaba se compraba en Valencia y Murcia, de donde se consumian en nuestra ciudad al finalizar el primer

38 A.M.T., Documento inserto en un cuadernilio sobre pleitos de visitas, Leg. Seda $n .^{\circ} 3$ (1691-1699) y Memorial de Damián de Olivares de 17-2-1626, Leg. Seda $n .^{\circ} 1$ (1500-1650). 
cuarto del siglo XVII unas 150.000 libras anuales por un valor de 1.500 .000 reales que generaban a su vez 3.000 .000 de reales gracias a los géneros que con ellas se laboraban. Es decir, el trabajo de elaboración producía una plusvalía del $100 \%$. Esta seda, repetimos, además de ser traída directamente por algunos maestros tejedores (los menos, por carecer la mayoría de ellos del capital suficiente para invertirlo de antemano) era puesta en el mercado por los que se dedicaban a comercializarla, unos comprándola por su cuenta, revendiéndola después y otros como comisionados o intermediarios. En Toledo se daba mucho la combinación del sistema gremial con la subordinación al capital mercantil por medio de los llamados «mercaderes de escritorio", principalmente dedicados al comercio sedero; los cuales compraban la materia prima que posteriormente proporcionaban a los artesanos tejedores ya preparada y dispuesta para la elaboración de tejidos, cintas, cordones, etc., les pagaban un salario por su trabajo o una cantidad prefijada por la fabricación y entrega del género solicitado que ellos se encargaban posteriormente de comercializar.

Toledo era un centro sedero donde la producción era continua. Se fabricaba sin cesar, sacando tejidos de seda para las Indias, Portugal, Galicia, Vizcaya, Aragón, Extremadura, Andalucía, Castilla la Vieja, el propio reino de Toledo y para el resto de España. Esta producción permanente, argumenta Damián de Olivares, hubiera sido imposible si faltara o escaseara la seda en la ciudad, pues entonces sólo unos pocos y ricos podrían sobrevivir comprándola directamente a los productores, lo que hubiera traído como consecuencia que ejercieran una especie de monopolio y vendieran al precio que quisieren sus géneros. Por el contrario, continúa, es buena la abundancia de seda, pues con ello aumentaría el comercio y la producción, se podrían dar las mercaderías a plazos sin recargo, lo que a su vez provocaría un mayor movimiento productivo y comercial y haría bajar los precios. Expone, como ejemplo, que hubo una gran cosecha de grano, pero vinieron las crecidas del río y no se pudo moler. Entonces, ejerciendo una excelente política, el Ayuntamiento concedió libertad en el precio del pan, con lo que los panaderos, por el ansia de obtener un gran beneficio, buscaron donde moler y vino la abundancia de pan y su abaratamiento.

El verdadero y único camino, según él, era que viniese a Toledo la abundancia de materias y mercaderías, pues sólo con esta libertad aumentaría el negocio y se abaratarían los productos, camino que dice es el que "siempre se ha conocido en los negocios".

Se muestra como un hombre totalmente «liberal» manifestándose partidario a ultranza del libre comercio interior. Según su criterio las normativas 
estrangulaban el comercio y el exceso de celo de las justicias le perjudicaba muchísimo, reduciéndolo y produciendo un alza del precio de los productos por escasez de los mismos, quedando mucha gente sin posibilidades de ganar un salario con el que poder subsistir.

Es partidario de la existencia de revendedores o intermediarios, pues dice que ellos procuran fiar a los tejedores para que puedan labrar (lana y seda). El libre comercio y la abundancia de tratantes, intermediarios o comisionados, aunque sean ricos y poderosos, procuran el crecimiento de la fábrica, el aumento del trato y comercio de mercaderías con un mayor abasto de los géneros que, como consecuencia, reduce su precio, dice. Además, el comercio seria prácticamente imposible sin estos comisionados o intermediarios,y si no, ¿cómo se haría para realizar las contrataciones entre reinos lejanos? Si las ventas de materias o géneros tuviesen que hacerlas los dueños directamente, sólo se harian una de ciento y en ésta procuraría venderla a un alto precio para paliar los gastos que conlleva este trajín o caería en la ruina. Lo mismo ocurriría si fuesen los compradores los que tuvieran que acudir directamente a comprar los productos, pues la mayoría, por falta de caudal, no podría hacerlo y la fábrica se perdería, y además haria daño a los productores de seda que se verian obligados a darla más barata por falta de compradores y se la llevarian los comisionados extranjeros que la acapararian, dejando a España sin ella.

Contra los que aseguraban que la subida del precio de las sedas estaba causado por el "estanco" que de ellas hacían algunos hombres de negocios, comisionados de los productores valencianos y murcianos, Damián de Olivares expone que la carestía era general en el reino y que habían subido de precio todos los géneros: jerguillas, estameñas, cordellates, bayetas y todos los géneros de paños altos y bajos, los cuales se habían incrementado en más del $50 \%$, y no sólo los tejidos de seda y que ello no era, como resulta obvio, culpa de los comisionados de la seda, pues no se puede achacar a cuatro hombres que trataban en un género la carestía general existente en España. La causa, aduce él, se hallaba en la abundancia excesiva del vellón ${ }^{39}$ que había hecho subir el valor de la plata un $56 \%$ y que según su pronóstico había de subir un $100 \%$ y aun con este premio daría barata la plata quien la poseyera. Basa su argumentación contra el vellón en el padre Mariana, quien en su «Historia General de España" daba varios ejemplos de carestías y subidas de precios por causa de la emisión de monedas de baja ley, cuando los monarcas la necesitaban coyunturalmente.

39 En esto, como en otras muchas cosas, coincide con Sancho de MONCADA. 
Opina que no es raro que la seda hubiera subido de precio pues habia que pagarla en Valencia en plata, ya que allí no admitían el vellón. Pero, sostiene, que peor seria si se tuviesen que pagar así los tejidos procedentes del extranjero, pues además de tenerlos que abonar en plata, no quedaría beneficio alguno en nuestro país.

Asimismo achaca el alza de precios a la existencia de una mayor demanda y gasto que hay de los tejidos de seda, tanto en el reino como en Indias.

Sin embargo, no se siente apesadumbrado ni preocupado por esta inflación; todo lo contrario, se congratula de ello pues opina que un mayor precio acrecentaria las ganancias y por el crecimiento de la demanda se aumentaría la fábrica y el comercio. Ello, a su vez, como en una cadena de causas-consecuencias, traería más trabajo con lo que aumentarían los oficiales, así como los géneros fabricados, y el exceso de producción haría moderar los precios.

Finaliza Damián de Olivares su escrito elevando al rey la petición de que se honre a las artes y se proteja a los hombres de negocios, que son los que proporcionan la riqueza a la nación con su comercio e industrias, y no permita que se les veje, calumnie o moleste pues con su actividad favorecen el bien común. Esta protección, cree el autor del memorial, animaría a otros a seguir el mismo camino, con lo que se conseguiría un incremento de la actividad comercial, lo que traeria una mayor riqueza al reino y un aumento de las Rentas reales «emanadas de la mayor riqueza y grangería de los naturales, y no de la contratacion de estraños".

En 1649 fue el gremio del Arte mayor de la Seda de Toledo el que solicitó, por medio de los mayordomos de la cofradía de N. ${ }^{a}$ S. ${ }^{a}$ del Rosario, Francisco de Cuéllar y Bosque y Juan Rodriguez Guerrero y de los veedores de dicho arte Alonso Medrano, Bartolomé Cano, Felipe Pérez y Diego de lllescas, que, para que se incrementase la actividad fabril, no se impidiese el comercio de sedas dentro de la ciudad con las visitas, pesquisas y continuas denunciaciones sobre mercaderes, hiladores y tintoreros, para comprobar de dónde se obtenía la seda, y pedian libre comercio dentro de la misma, sin trabas ni inconvenientes, quedando el seguimiento de la mercancía únicamente en las aduanas de las puertas de la ciudad, como se hacía en otros lugares de estos reinos, entre ellos Madrid, porque lo contrario era causa de que disminuyese el trato de las sedas en Toledo y se desviase la mercancía hacia la capital del reino ${ }^{40}$. En otras ocasiones

40 A.M.T., Escrito s/f (1649). En la sesión del Ayuntamiento de 12-4-1649 se ordena que unos comisionados se junten en la posada del Corregidor con los abogados y deliberen sobre la petición. Leg. Seda n. 1 (1500-1650). 
se solicitaba que se minorasen los derechos de alcabalas que pagaba la seda al entrar en la ciudad, pues al ser Madrid mercado abierto y no tenerse que pagar casi nada de alcabala por su encabezamiento, muchos mercaderes, maestros y fabricantes de Toledo habian puesto sus casas y trato en aquella ciudad, todo lo cual perjudicaba a la ciudad imperial, que quedaba sin actividad comercial e industrial y sin población.

No sabemos qué habría opinado y qué remedios habría expuesto $\mathrm{Da}$ mián de Olivares, ante el encarecimiento que experimentó la seda a lo largo del siglo, sobre todo en los últimos años, cuando pasó a valer en 1699 la libra toledana, de 16 onzas, 74 rs. de plata, siendo su valor en 1688 de 40 rs., y la libra valenciana (12 onzas) pasó de 30 rs. en 1688 a 50 en 1699 . Es decir, en once años, la primera subió un $85 \%$ y la segunda un $66,6 \%$.

Esta carestía, unida a la adulteración con seda ocal y la mezcla de diversos productos, lo que los fabricantes llamaban "carga maliciosa", y la merma que después de pasar por el tinte ${ }^{41}$ se producia, hacia que el costo de la seda se incrementara altamente. Todo ello, unido a otras causas que no es menester enumerar en este limitado trabajo, era motivo de la paralización de telares y de la subida del precio de los géneros en un $50 \%$ desde 1688. Como ejemplo diremos que la vara de fondo pasó de 40 rs. de vellón a 60 rs. en 1699.

Sólo queda decir que la actitud de este mercader, según trasciende de su memorial que aquí presentamos y comentamos, es mantener a ultranza la libertad de comercio. Es lo que hoy llamariamos un "neoliberal", mas sólo en lo que respecta al tráfico interior de mercancias, pues en cuanto a las relaciones comerciales con otros reinos era partidario de la doctrina mercantilista, aunque más podriamos hablar de «un proteccionismo de crisis que ambiciona una recuperación de urgencia, selectiva y provisional, especialmente hostil a cualquier prohibicionismo excesivamente ácido, alimentado por algunos de sus contemporáneos, con la esperanza semioculta de un porvenir de expansión que permita el retorno posterior a la libertad en el mar, como en los tiempos de la gran rivalidad portuguesacastellana" ${ }^{42}$.

Su pensamiento comercial se centraba en dejar libre, sin leyes restrictivas ni intromisiones institucionales, la actividad comercial, creyendo que ésta,

\footnotetext{
${ }^{41}$ La libra toledana (16 onzas), después de limpiada, quedaba reducida a 10 onzas y la valenciana (12 onzas) a 7,5 onzas cuando venia sin mixturas; la primera debia quedar, después de pasar por el tintorero, en 12 onzas aproximadamente.

${ }_{42}$ VILAR, Jean, “Un pessimisme "calculè"..., op. cit., págs. 134-135.
} 
por sí sola, únicamente con la ley de la oferta y la demanda, regularía el mercado, estabilizaría los precios y traería la riqueza y prosperidad de todos. Sin embargo, si era partidario de un proteccionismo de la industria y comercio nacionales para evitar que la riqueza marchara fuera de nuestra nación y procurar que prosperase y se incrementase nuestra producción, evitando así que fuesen los extranjeros los que medraran y se enriquecieran a nuestra costa. Por otra parte es de destacar la valentía con que, públicamente, defiende el honor de los mercaderes y comerciantes, en un pais en el que esta actividad no era muy bien vista por la mayoría de la población, que la identificaba de forma peyorativa con la raza judía o al menos de signo judaizante.

Ahora, y como colofón sólo queda transcribir el «Memorial de Damián de Olivares" impreso en Toledo con fecha 17 de febrero de 1626, y al que hemos respetado totalmente en su sintaxis, ortografía y puntuación, eliminando solamente algunos errores tipográficos. También nos hemos permitido la licencia de cambiar las " $u$ » por " $v$ » en aquellas palabras que en la actualidad así se escriben. (Ej.: Oliuares por Olivares).

\section{EL MEMORIAL}

\section{Muy poderoso Señor}

DAMIÁN de Olivares, natural de Toledo, digo que a mi noticia ha venido, que los Alguaziles Francisco de Aguilera, y Damian Bravo, han hecho denunciacion contra algunos mercaderes de Toledo, sobre dezir que estancan la seda en rama, para tornarla a vender, sin mudar de especie: y que compran los texidos para lo mismo: y que deilo se sigue grande excesso, y carestia de las mercaderias de seda en el Reyno; como mas largamente se contiene en su querella, a que me refiero. $Y$ porque esta causa toca en el comercio, el qual mas de ocho años que defiendo, procurando que en el Reyno no entren mercaderias de seda, ni lana labradas, sino que las nuestras se gasten, y el Reyno fabrique, y se quede en el la riqueza que los estraños adquirian con sus generos. $Y$ aviendo llegado el dichoso tiempo en que se avia executado, y siendo necessario alentar y amparar a los hombres ricos que fomentan y ayudan al comercio y fabrica, como lo tenia pedido en mis papeles, de que V.A. tiene noticia: en lugar desto los calunian con vexaciones, y denunciaciones, prendiendolos, y molestandolos, quitandoles sus creditos, y puniendolos en mala voz: causa de que no solo ellos lo dexaran, sino que otros muchos que se alentaran a acudir al comercio, perderan los animos, y lo dexaran de hazer; siendo en tiempo que es necessario todos empleen sus haziendas, para que se aumente la fabrica y lavor del 
Reyno, y podamos suplir la falta de los generos que entravan. $Y$ pues a este fin se tratava de fundar los Erarios, para formar caudales para el comercio del Reyno, justo serà alentar y ayudar a los que los emplean en el, como causadores de su aumento, que es el intento verdadero que con los Erarios se pretendia. $Y$ porque esto no parezca, escrivo, sin fundarme en buena razon, pretendo provar que lo que los dichos mercaderes hazen, es licito, sin que merezcan pena, sino antes premio.

Y para provar este caso, empeçaremos por lo que ellos llaman estanco; el qual propiamente podremos juzgar por los que ay Reales en el Reyno, que se hazen de un genero, estancandolo todo que corra debaxo una mano: y en los particulares, que se pueden llamar estancos, se entenderia quando en Toledo un genero que se contratava en el, le recogia sola una persona, haziendose señor del, y estancandole, para que passasse por su mano sola, y con esto darle el precio y estimacion que quisiesse. En esta denunciacion de seda corre contrario, porque si tratamos de la seda en rama, lo uno no es mercaderia que la ay en esta Ciudad, antes es necessario se trayga de fuera para proveella, y deste negocio ay en esta Ciudad mas de treinta casas que venden y negocian como los denunciados, unos que es suya, otros que se la embian de comision para vender: $y$ ademas destos ay otros que la traen para labrar en su casa, y fuera destos vienen forasteros cada dia a vender al meson de la seda, y grandes cantidades: y demas desto en los Reynos de Valencia, y Murcia, van libremente a comprarla de Sevilla, Cordova, Granada, toda la Andalucia, y otras muchas partes del Reyno, y otros muchos de Reynos estraños, Francia, e Inglaterra, y otros muchos particulares del Reyno, que los ay en Madrid, y otras partes, que la compran para tornar a vender, sin mudar de especie, y cosa que se tragina libremente por tantas manos, ansi en esta ciudad, como en otras partes, y Reynos: como pueden dezir que es estanco, ni que nadie la haze? fuera de que en esta Ciudad la seda que entra, seran ciento y cinquenta mil libras, poco mas o menos, que valdran millom y medio, que no es poderoso hombre nacido para hazer desto estanco.

$Y$ si quisieran dezir que le hazen alla en Valencia, o en Murcia, o en ambas partes, menos provable era, pues solo Valencia coge mas de quatrocientas mil libras, y Murcia cogerà otras dozientas mil, y entre Granada, y Estremadura, y lo demas de la tierra, criara mas de otras cien mil libras: pues si en esta Ciudad entran hasta ciento y cinquenta mil libras, en lo que viene aventurero, y en lo de comission, $y$ en lo de mercaderes para tornar a revender, y en lo que traen los que lo labran, y en los dichos Reynos se coge mas de setecientas mil libras: llano està y conocido que ni en lo que entra en esta Ciudad no ay estanco, pues passa por tantas manos; ni en lo de los Reynos que lo crian lo ay, pues para uno que aqui se gasta, se 
gastan seis en otras partes. $Y$ hablando derechamente, esto no han de llamar estanco, sino proveimiento y abundancia, pues traen el genero de la parte donde lo ay, para proveer la parte adonde falta.

Y pues tenemos llano con esto cessar el nombre que la dan de estanco, tratemos si es dañoso el comprar la seda en rama, para tornarla a vender en el especie que la compran, y si tienen pena por venderla ansi: $y$ assimismo si viene daño y perjuizio que se compren los texidos para tornarlos a vender. Para lo qual hemos de considerar que las fabricas es un general compuesto de ricos y pobres, y que los ricos son pocos, y los pobres el general y el todo de la fabrica, y para aumento della es necessario que a estos pobres aya quien los socorra hombres de caudal, ansi fiandoles las materias para que tengan de que fabricar, como quien les compre la mercaderia fabricada luego como la acaben, para ser socorridos, y que no cesse su lavor: y si esto cessasse, el estanco que oy se procura evitar, se causaria, porque faltandoles a los chorrillos (que llamamos) los dichos socorros, cessarian, y se quedaria la fabrica en pocos, y ricos, de que se causaria falta de mercaderias, y ellos como pocos, y solos venderian con la fuerça que quisiessen; lo que oy no pueden, porque como los chorrillos han menester vender en tiniendo la pieza, contentanse con moderada ganancia, acomodando el precio, y aun contentandose con sola la ganancia de la manifatura de sus manos, y con el precio que hazen, obligan a los ricos a vender. $Y$ dezir que un hombre solo puede estancar a Toledo, comprando los texidos que se hazen en el, es razon dicha de quien tiene poco conocimiento de la fabrica de Toledo, discurriendo y tratando de aquello mismo que ignora: porque Toledo es un centro que fabrica sin cessar, y se saca del para la cargazon de Indias, para Portugal, Galicia, Vizcaya, Aragon, Estremadura, Andalucia, Reyno de Toledo, Castilla la vieja, y para todas las demas partes de España, y no solo no se pueden agotar, sino que mientras mas le sacan, mas fabrica. $Y$ si dixe que la seda en pelo que entra en Toledo valia millon y medio,labrada valdra mas de tres millones, moderada cantidad por cierto para dezir que della haze estanco un hombre solo, cosa impossible, aunque fueran muchos; y siendo esto assi quieren fundar y provar que con un negocio que tiene puesto en Madrid, estanca las mercaderias: $y$ el dicho negocio antes es util, y conviniera que en Madrid no fuera solo, sino que huviera otros muchos como el, porque las tiendas, y negocios de Madrid que varean, son muchos, unos ricos, y otros moderados, que con poco caudal, y sus creditos, passan, y estos son los mas, y si no huviesse quien los proveyesse de mercaderias, acomodandolas de tiempo, con la misma comodidad de precio que compran de contado, cessarian sus negocios, y se quedarian en pocos, y poderosos, de que resultaria el verdadero estanco que oy dizen que ay y ansi el 
cierto camino que yo hallo para comodidad de las mercaderias, es que aya muchos que traten en ellas: que por la misma causa que sienten ganancia, todos procuraràn traer y proveer, de que resulta la comodidad: que la verdadera falta es de que la ay de la materia, por esperiencia lo conocemos oy en esta Ciudad de Toledo, pues aviendo las crecientes tan grandes que ay, de que han faltado las moliendas, por la misericordia de Dios tenemos el pan sobrado. No faltò la materia, y la prudencia del govierno, para proveer su Ciudad dio libertad de precio, con que los panaderos buscan donde moler, con la codicia del ganar, de que resulta estar sobrado, y la misma abundancia haze baxar y abaratar el precio: y si la falta fuera por falta de trigo, al impossible no ay trazas: y ansi hemos de considerar que el verdadero camino es, que todos procuren traer y llenar ansi a Toledo, como otras partes, de materia, y mercaderias, que con esta libertad haran aumento, y el mismo aumento causarà barato. Este es el camino derecho, y lo que siempre se ha conocido en los negocios.

$Y$ porque los dichos denuncian, de que revenden las sedas en especie, sin mudallas, y que compran texidos para venderlos, parece que quieren mostrar que ay prohibicion dello, la qual no solo no ay, sino antes expressamente permitido que libremente se haga, y venda, sin por ello aver cometido delito, ni tener pena alguna: y en esto no hablemos a caso, sino con leyes del Reyno, que hablan en propios terminos, ansi en estas materias, como en otras, en razon del revender. Aviendose proveido por prematica, fecha en Toro a 23. de Abril, del año de 1552. que ninguno pudiesse comprar carnes vinas para las tornar a revender, ni huviesse en ellas regatonerias, y ansimismo ganado de cerda, sino fuesse comprando en dias de ferias, y mercados: y por otra prematica fecha en la villa de Madrid, a 25. dias del mes de Mayo, del dicho año, que no se pudiesse comprar pastel, rubia, alumbres, rassuras, cueros al pelo, ni obras fechas de guadameciles, ni otros generos, para las tornar a vender: en el año de 1558. en Valladolid se proveyò carta acordada, en que suspendian las dichas prematicas, para que libremente lo dicho se pudiesse comprar y vender; dando por razon en la dicha carta acordada, que la experiencia avia mostrado que lo que entendieron resultaria en provecho, avia resultado lo contrario, y que no solo no se siguio el efecto que se penso, antes por razon de las molestias, vexaciones, achaques, y penas que para la execucion de lo susodicho hazian los juezes, justicias, y executores, a los que vendian las dichas mercaderias, se avia disminuido, y cessado gran parte del comercio, criança de ganados, y mercaderias, de que resultava la falta, y della mayor carestia: demas de que los subditos y vassallos eran molestados con muchas penas, y calunias, y que por los restinguir y limitar tanto el comercio y contratacion, no tenian en que se ocupar, ni de que vivir; de 
manera que lo que se proveyò en beneficio publico destos Reynos, y de los subditos, y naturales dellos, redundava en su daño y perjuizio: y por estas expressas razones que dize la dicha carta acordada lo suspenden. $Y$ ansimismo estando proveido el dicho año de 1552. por prematica, que ninguno pudiesse comprar lana para tornar a revender: en la Cortes de Valladolid, del año de 1555. por la peticion 82. dellas, suplicó el Reyno se suspendiesse la dicha prematica, porque del dexar de aver revendedores de lana, se hallavan muchos daños, e inconvenientes, y que era necesario que huviesse quien fiasse a los pobres lana con que pudiessen labrar: y en la respuesta de la dicha peticion, dize por palabras expressas: que porque por experiencia se avia visto el poco fruto que avia resultado de la dicha prematica, antes otros daños, e inconvenientes, avian mandado y mandavan suspender todo lo contenido en ella, que no se guardasse, ni executasse hasta que otra cosa se proveyesse sobre ello. $Y$ en la prematica que V.A. oy ha proveido, del tanteo de las lanas del Reyno, previno y reconocio lo mismo, pues pudiendo prohibir que no huviesse compradores de lanas para revender, no lo hizo, sino que los dexa libres que lo puedan hazer, con que se las puedan tantear como a los que las sacan del Reyno, reconociendo que era menester huviera quien fiara, y socorriera a los pobres. $Y$ ansimismo estando proveida prematica Real, en Madrid, a 3 . de Junio de 1600. años, que ninguno pudiesse comprar seda para tornar a vender sin mudar de especie, aviendose conocido desto mayores daños e inconvenientes, se suspendio, por carta acordada de V.A. el año de 1608. para que libremente cada uno lo pudiesse comprar, y vender como quisiesse, sin pena alguna. $Y$ aviendo hecho otra denunciacion sobre lo mismo en esta dicha Ciudad de Toledo a los dichos mercaderes, y a otros, fueron dados por libres en la Real Chancilleria de Valladolid, de lo qual se despacho carta executoria, su fecha en Valladolid a 19. de Enero de 1619. años: de suerte que conforme esto conocemos que por experiencia siempre se ha visto que conviene estè libre la contratacion del comercio, generalmente en todas cosas, pues por las leyes por mi alegadas, se vee no solo en este mismo genero de que tratamos, sino en todos los demas, y que la propia abundancia de tratantes, y correspondientes, aunque sean ricos y muy poderosos, que es lo quellos mas acriminan, hazen la abundancia de la fabri$\mathrm{ca}$, trato, y comercio de las mercaderias, y que aquella riqueza que ponen por delito, causa la abundancia y mayor abasto de todos los generos.

Y porque he oydo a algunos, con ignorancia del conocimiento del comercio, dezir que el mayor beneficio que se puede hazer, es quitar las comissiones, que sirven como de estanco, y que si no las huviesse, los propios dueños de las mercaderias, y materias, las traerian a vender, y que se causaria mas barato. $Y$ porque destas hablas no resulte algun per- 
juizio grande del comercio, hemos de reconocer que la contratacion por comisiones, es el medio mas suave que se ha hallado para la conservacion del comercio. Vamoslo juzgando por las contrataciones estrañas, para las Indias sino fuera por medio de comissiones, como se pudiera cargar? todos los cargadores que ay en España, que cargan sus mercaderias, y las remiten a sus comissionados, sino fuera por este medio, y huvieran de cargar, e yr por sus personas no cargara uno. Las contrataciones de Flandes, Italia, y otros Reynos estraños con España, y ellos unos con otros, sin medio de comissiones como se hizieran, ni trataran? Pues que mas tendran estas, que las que ay en estos Reynos de España, de un Reyno a otro, y de un lugar a otro, de Valencia a Castilla, si toda la seda que viene, assi cruda como labrada, huviera de venir cada dueño della en persona? de cien partes no viniera una: y el que viniera hiziera tanta costa, que avia de suceder una de dos cosas, o para sanearla venderla a excessivo precio, o perderse en ella: lo uno y lo otro no conviniente, pues el encarecerse fuera el daño que pretenden evitar, $y$ el perderse mayor: que si todos los que van contratando se pierden, sera cessar y acabarse todo. Y lo mismo sucediera en los compradores, si les fuera fuerça yrla a comprar toda, no viniendo: y los pobres, que son los mas, carecieran del todo della, pues no tuvieran caudal, ni orden de comprarla fuera de que los hombres de negocios, ansi los que embian seda en rama, como los que la embian labrada, mientras aca les estan vendiendo la que embiaron, estan ellos texiendo, o torciendo otra para embiar: de suerte que es como una rueda que anda sin cessar, que es el camino mas derecho para el aumento de las fabricas, que los que las fabrican tengan medio de su despacho, sin cessar ellos su lavor, que fuera esta otra cost, y daño para ellos. $Y$ ha se de advertir que en Valencia ay agentes, y comissionarios estrangeros, de Francia, y otros Reynos, que en baxando la seda tres 0 quatro reales por libra, la atraviessan y compran toda: de suerte que si aca se les quitasse el medio de la facilidad de su contratacion, les forçaria a baxar de precio, y la venderian a los estraños, y España se quedaria sin seda. Demas que la ciudad de Valencia ha pretendido quitar a Castilla la seda en rama, y que no entrasse aca sino fuesse fabricada en texidos, y para ello avra cinco años que hizo junta, en que ordeno que se quitassen de las villas del Reyno los tornos, y telares que avia, y fuessen obligados a llevar a la dicha ciudad toda la seda a torcer, y labrar: y para ello se les registrasse en capillo en las mismas andanas donde se cria, y otras ordenes de opression: y contra todo esto yo escrivi un memorial, y a mi instancia salio Toledo a la causa, y embiò Comissarios que hizieron las diligencias necessarias sobre ello, y don Luis Blasco Cavallero del habito de Montesa, que oy es del Consejo de Aragon, vino por diputado de las villas, 
contra la dicha ciudad, con que cesso: y si aora se quitase, o acortasse con estas denunciaciones, la libertad de la contratacion de la seda de aquel Reyno con Castilla, lo que no pudo alcançar contra nosotros con su mano, lo vendria a conseguir con la nuestra. De suerte que lo que representan por daño, y carestia, es el verdadero camino para el abasto de mercaderias, y moderacion de precios: y este mismo camino corre en las mercaderias de aca de Castilla, que el que vive en Toledo, tenga negocio correspondiente en Madrid, y su comissonario, y que destos aya muchos, para que estos sin cessar su trato aca, despachen sus mercaderias alla, y los mercaderes de tiendas de alla, sin salir de sus casas, ni dexar sus negocios, hallen alli las mercaderias comodas, sin gastos, ni costas, y siempre prevenidos para que no les falte oy ni mañana. $Y$ lo mismo corre en las correspondencias de unos lugares con otros en toda España, cosa que siempre ha corrido, sin ser novedad, ni que dello se aya podido reconocer daño ninguno: de suerte que conforme a esto conocemos el util y beneficio destas comissiones, y modo de contratar, con que cessara lo que habla el vulgo ignorante.

Y porque en lo que mas se han fundado, para representar delito en su denunciacion, ha sido dezir que se ha causado gran carestia en el Reyno, es razon fundemos las verdaderas causas de la carestia, provando no emana de lo que ellos dizen.

Para lo qual se ha de considerar que oy en el Reyno quantos generos ay se han subido, y que la verdadera causa desta subida no ha sido el estanco que ellos dizen en las sedas: las jerguillas, estameñas, cordellates, valletas, todos generos de paños baxos, y altos, que han subido mas de la mitad, quien las revende, o estanca, o quien ha causado este excesso? de suerte que si generalmente todo ha subido, frivolo y sin fundamento es asir de quatro hombres que tratan en un genero, siendo la carestia general en todos, y en todo el Reyno. La verdadera causa, y principal de la carestia destos Reynos, es el excesso del vellon de tanto valor extrinseco, sin valor intrinseco ninguno, causa de aver subido el premio de la plata oy a cinquenta y seis por ciento. y la subida aun no la tengo por grande, porque entiendo ha de subir a ciento por ciento; y bien considerado aun con este premio da barata la plata el que la tiene, pues un real de plata, que el metal del vale verdaderamente treinta y cuatro maravedis, aunque le den dos de trueco por el, no queda pagado, pues en los dos reales de vellon no lleva mas que doze, o catorce maravedis, a lo mas largo, que valen dos onzas que pesa el cobre dellos, y estas con tan poco aprovechamiento, que aun para qualquier uso son de poco valor. Cosa es, muy poderoso Señor, esta de la corrucion de la moneda de vellon, sin valor intrinseco, que siempre que en España la ha avido, ha causado daños, y carestias en 
las mercaderias, y comercios destos Reynos. Esto nos lo dixo elegantemente el padre Mariana en su Coronica general de España, en el primer tomo, a 635. planas, en la 2. coluna, donde dize que se hizieron en tiempo del Rey don Alonso monedas negras, y burgaleses, baxas de ley, de que se causaron grandes carestias. $Y$ en el segundo tomo, a 101. planas, a la segunda coluna, dize que el Rey don Enrique hizo labrar dos generos de monedas, por necessidad que tuvo de mala y baxa ley, la una llamada cruzados, y la otra reales y que aunque de presente salio de aprieto, para adelante fue muy perniciosa, y mala, porque a esta causa los precios de las cosas subieron a cantidades muy excessivas. $Y$ en el dicho tomo, a la plana 398. en tiempo de los Reyes Catolicos, al fin de la segunda coluna, dize que la moneda era falsa, o baxa de ley, cosa de gran perjuizio para los mercaderes, y contratacion; y que siempre sucede en los Reynos que se labran las monedas baxas de ley. $Y$ si por la dicha mala moneda oy se ha encarecido generalmente todo a excessivos precios, con ser las mas cosas dellas generos que se comercian y contratan con vellon, que maravilla es que la seda aya subido lo mismo siendo cosa que precisamente se compra con plata, porque la materia es genero que se trae de Reynos donde el vellon no es moneda, ni passa, y es fuerça que la reducion del premio ha de cargar, y ser de mayor precio: $y$ considerando esto, como en efecto es verdad, hemos de mirar que el genero que menos ha subido, $y$ que mas barato se vende, es la seda, pues vendiendose a cien reales, no sale de venta por sesenta y quatro de plata, que es la moneda en que se paga: y yo me acuerdo comprar un fondo dos pelos por quarenta y ocho, y cinquenta reales, que no los vale oy, y era en tiempo que ni avia premio, ni se sabia que era: y aviendo avido entonces aquella subida, no se reparò, y reparase oy que aun no vale tanto, teniendo el daño tan grande del premio. $Y$ bien considerado el mayor beneficio que tenemos, ya que el Reyno està en este estado de moneda, es que nuestras mercaderias de lana, y de seda, aunque sean caras, se traginen, y fabriquen, y gastemos entre nosotros, porque el daño se dissimula, con que comerciamos con nuestro vellon, y la ganancia de la fabrica, y contratacion se queda entre nosotros porque si entraran mercaderias estrañas, era fuerça encarecernoslas a excessivo precio, por la subida de la plata, que es la moneda que avian de sacar en precio dellas, y vistieramos tan caro y mas de lo estraño, que de lo nuestro, y la ganancia de nuestro comercio perdieramos, y quedaramos por dos partes perdidos, en lo que ellos llevaran mas por lo que vestiamos, y en lo que perdieramos, por lo que dexaramos de fabricar, y contratar. Demas que se ha de considerar, que el mayor precio que oy corre en las mercaderias de lana, y seda, tambien se ha causado de contratarse nuestros generos solos, sin entrar los estraños, por la mayor demanda y gasto 
que ay dellos, ansi en el Reyno, como para la cargazon de Indias. Demas de que esta subida es util, porque el mayor precio causara traer mas riquezas en trueco de nuestros generos, y por la mayor demanda, se aumentara mas la fabrica, y se animaràn todos con la codicia del ganar, comerciando, traginando, cargando, o fabricando, y avra mayor abundancia de oficiales, que se aumentaran cada dia, y de todo este aumento se causarà mayor abundancia de generos, pues se adquiere mas riqueza, ni lo serà adelante, pues se vendra a moderar con el aumento de todo.

Muy poderoso Señor, pues los comercios de España quiere Dios que empiezen a andar, y es necessario aya caudales, y que el comercio se aumente, suplico a V.A. passe los ojos por este memorial, y recuerde en si lo que en otros tengo pedido, que se honren las artes, y a los hombres de negocios, para que se animen a proseguir y aumentar el comercio, y V.A. no consienta vexaciones, ni calunias injustas, considerando que nunca denunciadores, ni caluniadores tratan del bien publico, ni les mueve caridad, sino su interes particular; y como padre de la patria, acudiendo a la verdad del hecho, favoreciendola, y a los que hazen provecho a bien comun los ampare y defienda, para que libremente comercien, y fabriquen, y otros se animen de nuevo a lo mismo: que con esto se conseguirà el verdadero camino del aumento de nuestro comercio, y con el la moderacion de precios, y riqueza del Reyno, y las Reales rentas se aumentaràn, y seran fixas, y perpetuas, como emanadas de la mayor riqueza y grangeria de los naturales, y no de la contratacion de estraños. y pues siempre mi zelo ha sido limpio, solo con intento de tratar del bien comun, y remedio de los pobres del Reyno, humildemerite suplico me perdone, y admita mi buena voluntad V.A. que prospere nuestro Señor largos años, etc. Toledo, y Febrero 17 . de 1626 . 